\title{
Effect of Dietary Starch Inclusion Rate on Digestibility and Amylase Activity in Arctic charr (Salvelinus alpinus) and Eurasian perch (Perca fluviatilis)
}

\author{
Rani Abro, Torbjörn Lundh and Jan Erik Lindberg* \\ Department of Animal Nutrition and Management, Swedish University of Agricultural Sciences, Uppsala, Sweden
}

\begin{abstract}
This study investigated digestibility and amylase activity in Arctic charr and Eurasian perch fed different dietary levels of wheat starch. Eurasian perch $(190 \pm 0.5 \mathrm{~g})$ and Arctic charr $(102 \pm 0.5 \mathrm{~g})$ were fed one of six iso-nitrogenous diets containing 0,10,15,20, 25 and 30\% wheat starch. Each diet was fed to four replicate groups of fish to determine the impact of diet on the apparent digestibility (AD) of dry matter (DM), crude protein, starch, crude fat and energy. At the end of the experiment, tissue samples were collected for assessment of amylase activity in the proximal and distal intestine. The AD of DM, crude protein, starch, crude fat and energy differed between fish species $(P<0.001)$, with on average higher values for all parameters in Eurasian perch than in Arctic charr. Within fish species, there was no effect $(P>0.05)$ of dietary starch level on the AD of DM, crude protein, crude fat and energy. Overall, $\alpha$-amylase activity correlated with the trends obtained for starch digestibility. The inclusion of wheat starch did not affect amylase activity within species.
\end{abstract}

Keywords: Arctic charr; Eurasian perch; Digestibility; Starch; Amylase

\section{Introduction}

Arctic charr (Salvelinus alpinus) and Eurasian perch (Perca fluviatilis) are two important and highly appreciated finfish species in the Scandinavian countries. Both species have been identified as promising candidates for increased production [1,2] using either oligotrophic freshwater sources or recirculating aquaculture systems (RAS) as the basis for cultivation [3]. However, there is limited knowledge about the dietary requirements and possible limitations in diet composition when culturing these fish species. Nutritional studies have been performed on protein and lipid digestion and requirements in Eurasian perch [4,5] and Arctic charr [6], but little is known about the impact of dietary levels of carbohydrates $[7,8]$. Both species are classified as carnivorous and therefore feeds formulated for salmonids and sea bass have been used for intensive Arctic charr and Eurasian perch culture, although they may not meet the nutritional requirements of the fish [9].

Inclusion of easily available carbohydrates in the diet at the expense of fat can be a way to reduce feed costs. It can also have a protein saving effect [7], which should make it possible to decrease the dietary protein content without negative effects on fish performance. It has been shown that a proper balance between dietary carbohydrates and fat in the diet influences the protein saving effect in salmonids, pikeperch (Sander lucioperca) and Eurasian perch, and may even lead to improved growth performance $[5,10]$. However, in general, the utilisation of dietary carbohydrates for energy purposes in salmonids and other carnivorous fish species appears to be limited $[11,12]$.

The utilisation of carbohydrates in fish varies between species $[7,13,14]$ and with different types and sources of carbohydrates [12]. For example, channel catfish, common carp, red sea bream, tilapia and yellowtail grow better when fed starch rather than glucose [15-17], whereas white sturgeon and chinook salmon utilise dietary glucose more efficiently than starch. Moreover, native starches seem to better digested in European sea bass (Dicentrarchus labrax) and gilthead sea bream (Sparus aurata) than in other carnivorous species [12].
Fish can modulate their digestive enzyme activity in response to the level of dietary intake and composition of the feed, and the enzyme activity may change with fish development stage $[18,19]$. Moreover, Arctic charr and Eurasian perch seem to respond differently to dietary carbohydrates [7], which could be related to differences in gut amylase activity. Thus, the present study examined the effect of diets containing different levels of wheat starch on digestibility and amylase activity in Eurasian perch and Arctic charr.

\section{Material and Methods}

\section{Diets}

Six iso-nitrogenous diets containing different levels $(0,10,15,20,25$ and $30 \%$ by dry weight) of raw wheat starch (diets WS0, WS10, WS15, WS20, WS25 and WS30) were formulated using fish meal (50\%) and gelatin $(7.1 \%)$ as protein ingredients. All diets contained lecithin (1\%) and a mineral-vitamin premix $(0.5 \%)$, and titanium dioxide $(0.5 \%)$ was included as an indigestible marker for digestibility calculations. The mineral-vitamin premix provided (per kg diet): $200 \mathrm{mg}$ cobalt sulphate, $1,000 \mathrm{mg}$ copper sulphate, $200 \mathrm{mg}$ iron sulphate, $600 \mathrm{mg}$ potassium iodide, 3,000 mg manganese sulphate, $24,000 \mathrm{mg}$ zinc sulphate, 500 IE retinol acetate, $300 \mathrm{IE}$ cholecalciferol, 4,000 $\mathrm{mg}$ alpha tocopherol acetate, 2,000 mg sodium menadione bisulphate, 3,000 mg thiamine$\mathrm{HCl}$, 5,000 mg riboflavin, 6,000 $\mathrm{mg}$ calcium pantothenate, $15,000 \mathrm{mg}$ nicotinic acid, 3,000 $\mathrm{mg}$ pyridoxine $\mathrm{HCl}, 1,000 \mathrm{mg}$ folic acid, $4 \mathrm{mg}$

*Corresponding author: Jan Erik Lindberg, Department of Animal Nutrition and Management, Swedish University of Agricultural Sciences, Uppsala, Sweden Tel: +46-18-672102; Fax: +46-18-672995; E-mail: jan.erik.lindberg@slu.se

Received September 19, 2013; Accepted November 28, 2013; Published December 02, 2013

Citation: Abro R, Lundh T, Lindberg JE (2013) Effect of Dietary Starch Inclusion Rate on Digestibility and Amylase Activity in Arctic charr (Salvelinus alpinus) and Eurasian perch (Perca fluviatilis). J Aquac Res Development 5: 209 doi:10.4172/2155-9546.1000209

Copyright: (c) 2013 Abro R, et al. This is an open-access article distributed under the terms of the Creative Commons Attribution License, which permits unrestricted use, distribution, and reproduction in any medium, provided the original author and source are credited. 
cyanocobalamin, $50 \mathrm{mg}$ biotin, 25,000 $\mathrm{mg}$ ascorbic acid and $400 \mathrm{mg}$ inositol. Cellulose (25.0\% in WS0 to $7.1 \%$ in WS30) and fish oil (15.9\% in WS0 to $2.0 \%$ in WS30) were used to adjust the diet composition and to maintain a reasonable range of gross energy (GE) content (Tables 1 and 2). The ingredients for the diets were finely ground, mixed thoroughly, dried and chopped to pellets approximately $2 \mathrm{~mm}$ in size.

\section{Fish rearing}

Arctic charr (Salvelinus alpinus) with initial mean weight of 102 $\pm 0.5 \mathrm{~g}$ were distributed into 24 polyvinyl chloride (PVC) tanks, with four replicate tanks per diet. The 16 fish in each PVC tank were fed the experimental diets for 30 days. The water temperature was maintained at $10 \pm 1^{\circ} \mathrm{C}$.

Eurasian perch (Perca fluviatilis) with an initial mean weight of 190 $\pm 0.5 \mathrm{~g}$ were distributed into 12 PVC tanks, with two replicate tanks per diet. This was repeated to get four replicates in total. The five fish in each PVC tank were fed the experimental diets for 30 days. The water temperature was maintained at $21 \pm 1^{\circ} \mathrm{C}$.

The six experimental diets were randomly allocated to each tank. The fish were acclimatised to the experimental conditions for two weeks before the start of the experiment. The Artic charr were fed by a belt feeder and the Eurasian perch were fed by hand, with a total daily allowance of $2 \%$ of body weight. During the experiment, feed

\begin{tabular}{|c|c|c|c|c|c|c|c|c|}
\hline & \multicolumn{6}{|c|}{ Diets } & \multirow[b]{2}{*}{ SEM } & \multirow[b]{2}{*}{ P-value } \\
\hline & WS 0 & WS 10 & WS 15 & WS 20 & WS 25 & WS 30 & & \\
\hline \multicolumn{9}{|c|}{ Content as analysed } \\
\hline Crude protein & 41.6 & 42.3 & 41.6 & 41.6 & 42.1 & 41.3 & & \\
\hline Crude fat & 18.9 & 17.8 & 16.5 & 11.7 & 8.4 & 10.2 & & \\
\hline Starch & 0.6 & 9.0 & 13.3 & 18.4 & 22.0 & 27.3 & & \\
\hline Ash & 7.0 & 6.9 & 7.0 & 6.9 & 7.0 & 7.0 & & \\
\hline Gross energy & 22.5 & 21.9 & 21.5 & 20.8 & 20.2 & 19.7 & & \\
\hline \multicolumn{9}{|c|}{ Apparent digestibility } \\
\hline Dry matter & $56.0^{\mathrm{b}}$ & $62.9^{a}$ & $57.6^{\mathrm{ab}}$ & $58.9^{\mathrm{ab}}$ & $59.0^{\mathrm{ab}}$ & $56.6^{\mathrm{b}}$ & 1.2 & 0.013 \\
\hline Crude protein & 84.5 & 85.7 & 83.1 & 83.6 & 84.4 & 84.1 & 1.1 & 0.615 \\
\hline Crude fat & $83.6^{\mathrm{b}}$ & $85.9^{\mathrm{ab}}$ & $88.4^{a}$ & $87.9^{a}$ & $84.5^{\mathrm{b}}$ & $85.1^{\mathrm{ab}}$ & 0.7 & 0.001 \\
\hline Starch & - & 42.8 & 36.0 & 34.5 & 35.1 & 35.8 & 3.7 & 0.513 \\
\hline Gross energy & 63.9 & 71.9 & 67.7 & 66.5 & 69.8 & 64.2 & 1.2 & 0.213 \\
\hline
\end{tabular}

Table 1: Chemical composition (\% of DM), gross energy content (MJ/kg DM) and apparent digestibility $(\%)$ of experimental diets with increasing inclusion $(0,10$, $15,20,25$ and $30 \%$ ) of wheat starch (WS) fed to Arctic charr Means with different superscript letters are significantly different $(P<0.05)$

\begin{tabular}{|c|c|c|c|c|c|c|c|c|}
\hline & \multicolumn{6}{|c|}{ Diets } & \multirow[b]{2}{*}{ SEM } & \multirow[b]{2}{*}{ P-value } \\
\hline & WS 0 & WS 10 & WS 15 & WS 20 & WS 25 & WS 30 & & \\
\hline \multicolumn{9}{|c|}{ Content as analysed } \\
\hline Crude protein & 42.4 & 46.7 & 45.7 & 43.1 & 42.2 & 40.6 & & \\
\hline Crude fat & 19.2 & 18.6 & 16.7 & 14.4 & 10.7 & 8.0 & & \\
\hline Starch & 0.6 & 8.7 & 13.5 & 17.7 & 21.7 & 26.9 & & \\
\hline Ash & 7.2 & 7.8 & 7.6 & 7.3 & 7.2 & 7.0 & & \\
\hline Gross energy & 22.5 & 22.1 & 21.9 & 20.1 & 20.2 & 19.4 & & \\
\hline \multicolumn{9}{|c|}{ Apparent digestibility } \\
\hline Dry matter & $62.5^{\mathrm{b}}$ & $69.8^{\mathrm{a}}$ & $68.2^{\mathrm{a}}$ & $66.0^{\mathrm{ab}}$ & $66.1^{\mathrm{ab}}$ & $65.1^{\mathrm{ab}}$ & 1.2 & 0.007 \\
\hline Crude protein & 91.7 & 89.5 & 87.8 & 91.8 & 90.0 & 89.6 & 1.9 & 0.704 \\
\hline Crude fat & 86.5 & 88.7 & 87.1 & 91.8 & 88.9 & 90.1 & 1.9 & 0.436 \\
\hline Starch & - & $68.0^{\mathrm{a}}$ & $57.3^{b}$ & $53.6^{\mathrm{b}}$ & $54.1^{\mathrm{b}}$ & $58.9^{b}$ & 1.7 & 0.001 \\
\hline Gross energy & $70.1^{\mathrm{b}}$ & $76.2^{\mathrm{a}}$ & $73.6^{\mathrm{ab}}$ & $73.0^{\mathrm{ab}}$ & $71.4^{\mathrm{ab}}$ & $70.2^{\mathrm{ab}}$ & 1.4 & 0.038 \\
\hline
\end{tabular}

Table 2: Chemical composition (\% of DM), gross energy content (MJ/kg DM) and apparent digestibility (\%) of experimental diets with increasing inclusion $(0,10,15$ 20, 25 and 30\%) wheat starch (WS) fed to Eurasian perch Means with different superscript letters are significantly different $(P<0.05)$. residues and faeces were removed every day by draining off onethird of the water and replacing it with new water. The fish accepted the experimental diets and no mortality occurred during the entire duration of the experiment.

\section{Digestibility}

In Arctic charr, faeces samples were collected from the distal intestine of all fish at the end of experiment and pooled to a bulk faeces sample for each tank. This was freeze-dried, finely ground and stored at $-20^{\circ} \mathrm{C}$ for further analyses.

In Eurasian perch, faeces samples were collected by settling columns connected to the fish tanks, based on the Guelph principle [20], as initial studies showed that not enough faecal material could be obtained through dissection. Faeces samples were collected twice per day from each tank for 30 days. After feeding, any remaining uneaten food residues and other waste material were flushed out from the tanks by opening the valve of the collection tube, followed by addition of new water. The faecal material was then allowed to settle and collected from the collection tube. Pooled samples from each tank were freeze-dried, finely ground and stored at $-20^{\circ} \mathrm{C}$ for chemical analyses.

The total tract apparent digestibility (TTAD) of the experimental diets was calculated as described by [20].

TTAD $($ dry matter $)=100-100 \times($ titanium oxide in diet $/ \%$ titanium oxide in faeces)

TTAD (nutrient $)=100-100 \times($ titanium oxide in diet $/ \%$ titanium oxide in faeces $) \times(\%$ nutrient or energy in faeces $/ \%$ nutrient or energy in diet)

\section{Amylase activity in the proximal and distal intestine}

At the end of experiment, the fish were anesthetised with a Tricane methane sulphonate (MS-222) solution $(50 \mathrm{mg} / \mathrm{L})$ for two minutes in an anaesthetic bath. The fish were then dissected and the proximal and distal intestines were removed, immediately transferred to liquid nitrogen and kept frozen at $-80^{\circ} \mathrm{C}$ until analyses. A total of 16 tissue samples were collected from each treatment for each fish species.

The amylase activity in gut tissue samples was analysed using the Ceralpha kit (Megazyme K-CERA, Wicklow, Ireland) according to the Ceralpha procedure (Sigma, St. Louis, MO, USA). The tissue samples were cut in small pieces and placed in ice-cold extraction buffer $(\mathrm{pH}$ 5.4) and homogenised in an electrical homogeniser (Ultra turrax tube dispenser, IKA Werke GMBH \& Co. KG, Staufen, Germany). The homogenate was centrifuged at $15,800 \mathrm{~g}$ for $10 \mathrm{~min}$. The supernatant was collected and the protease inhibitor phenyl methyl sulphonyl fluoride was added to a final concentration of $0.5 \mathrm{~mm}$. The samples were kept on ice until amylase activity analyses. The test tube, containing $100 \mu \mathrm{L}$ homogenate and $20 \mu \mathrm{L}$ amylase high range reagent solutions, was incubated for $20 \mathrm{~min}$ at room temperature. The reaction was stopped by adding $300 \mu \mathrm{L}$ stopping reagent (alkaline solution) followed by measurement of absorbance at $405 \mathrm{~nm}$ on a micro plate reader (Multiscan FC; Thermo Fisher Scientific Inc, IL, USA).

Enzyme activity (U/g) was calculated as: $\mu \mathrm{mol} / \mathrm{mL}$ (according to the standard curve) $\times$ final volume in well $\times$ dilution factor/sample volume $\times$ incubation time.

Total protein content in gut tissue samples was determined according to [21] using a protein assay kit (Micro BCA ${ }^{\mathrm{TM}}$ PIERCE, Rockford, IL 61105) with bovine serum albumin as the standard according to the manufacturer's instructions. 


\section{Chemical analysis}

The chemical composition of feed ingredients and faeces was analysed using standard methods [20]. Dry matter (DM) content was determined by drying at $105^{\circ} \mathrm{C}$ for $24 \mathrm{~h}$. Total nitrogen $(\mathrm{N})$ content was determined using the Kjeldahl method and crude protein $(\mathrm{CP})$ was calculated as $\mathrm{N} \times 6.25$. Crude fat (EE) content was determined by the Soxhlet method after acid hydrolysis of the sample. Ash content was determined by incineration in a muffle furnace at $550^{\circ} \mathrm{C}$ for $12 \mathrm{~h}$. Gross energy content was determined with a bomb calorimeter (calorimeter Parr 6300, Parr Instrument Company, Molin, IL, USA). Titanium oxide concentration was measured according to [22].

\section{Statistical analysis}

Statistical analysis of the data was performed using the MINITAB ${ }^{\circledR}$ statistical software package (Version 16; Minitab, State College, Pennsylvania) under Proc GLM. The TTADs of the nutrients were compared by two-factor orthogonal ANOVA (factors: diet and species). Significant differences were detected by Tukey's pairwise comparison test at probability level $p<0.05$. The effect of diet on enzyme activity was similarly analysed for the factors: diet, species and diet, and region of intestine.

\section{Results}

\section{Apparent digestibility}

The AD of DM, starch, CP, EE and GE in the experimental diets in Arctic charr is shown in Table 1 and in Eurasian perch in Table 2.

The AD of DM in Arctic charr was higher $(\mathrm{p}=0.013)$ for diet WS 10 than for diets WS0 and WS30, while there were no significant differences in $\mathrm{AD}$ of $\mathrm{DM}$ between the other diets. The $\mathrm{AD}$ of $\mathrm{EE}$ was higher $(\mathrm{p}=0.001)$ for diets WS15 and WS20 than for diet WS0. There were no significant differences in the $\mathrm{AD}$ of $\mathrm{CP}$, starch and $\mathrm{GE}$ between dietary levels of starch inclusion in Arctic charr.

The $\mathrm{AD}$ of $\mathrm{DM}$ in Eurasian perch was higher $(\mathrm{p}=0.007)$ for diets WS10 and WS15 than for diet WS0. The AD of starch and GE was higher ( $p=0.001$ and $p=0.038$, respectively) for diet WS10 than for all other diets. There were no significant differences in the $\mathrm{AD}$ of $\mathrm{CP}$ and EE between levels of starch inclusion in Eurasian perch.

The AD of DM, CP, EE, starch and GE differed between fish species $(\mathrm{p}<0.001)$, with consistently higher $\mathrm{AD}$ values in Eurasian perch than in Arctic charr. Across dietary treatments, the AD of DM, CP, EE, starch and GE was on average $66.3,90.1,88.8,58.4$ and $72.4 \%$ in Eurasian perch, and 58.5, 84.2, 85.9, 36.8 and 67.3\% in Arctic charr. The most striking difference in $\mathrm{AD}$ between the fish species was found for starch, where the average $\mathrm{AD}$ differed by $21.6 \%$ units. There were no significant diet-species interactions on the $\mathrm{AD}$ of the dietary components analysed.

\section{Amylase activity}

The $a$-amylase enzyme activity in the proximal and distal intestines is shown in Figure 1. Total protein content in the proximal part of the intestine differed between species $(\mathrm{p}<0.009)$, with higher values in Eurasian perch than in Arctic charr, while there was a non-significant $(p>0.05)$ difference in total protein content in the distal part of the intestine. Within species, the total protein content in gut tissues did not differ at different starch inclusion levels.

Between species, $\alpha$-amylase enzyme activity was higher in Eurasian perch than in Arctic charr $(\mathrm{p}<0.001$ and $\mathrm{p}<0.006$ in the proximal and

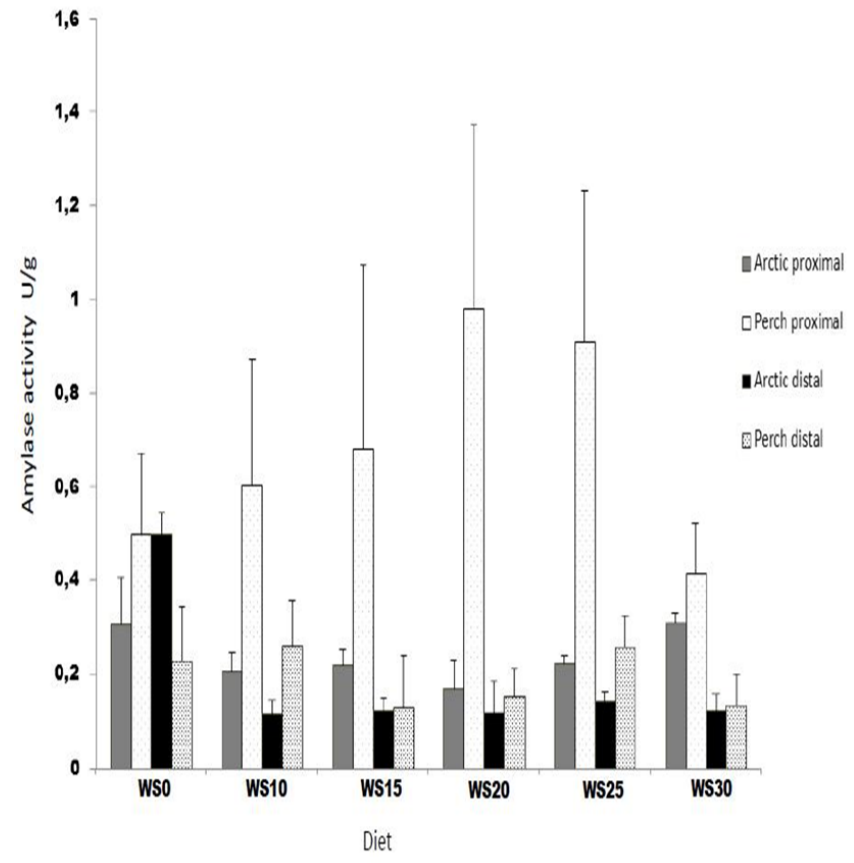

Figure 1: Level of $\alpha$-amylase activity in the proximal and distal intestine of Arctic charr and Eurasian perch fed diets with different levels $(0,10,15,20,25$ and $30 \%$ ) of raw wheat starch (WSO-WS30).

distal parts of the intestine, respectively). The $\alpha$-amylase enzyme activity in the proximal region was higher than in the distal region $(\mathrm{p}<0.001)$ in both species. There were no significant diet-species interactions on $\alpha$-amylase activity in the proximal and distal gut.

\section{Discussion}

The $\mathrm{AD}$ of dietary components and energy proved to be higher in Eurasian perch than in Artic charr. The difference between species was most pronounced for starch, where the AD was more than $20 \%$ -units higher in Eurasian perch than in Arctic charr. It has been shown previously that the digestibility of nutrients in fish differs between species and is influenced by factors such as age, temperature, diet composition and ration level [23,24]. For carbohydrates in particular, there are large differences in the digestive capacity between carnivorous, omnivorous and herbivorous fish species [7,23]. However, important differences between carnivorous fish species in terms of digestive capacity and utilisation of carbohydrates have also been reported [12]. The low starch digestibility in Artic charr found in the present study confirms previous findings in other salmonids $[7,8,11,25]$, suggesting that it is due to long-term adaptation and selection related to their food habits.

According to [26], almost all digestive enzymes are present in carnivorous, omnivorous and herbivorous fish species, irrespective of differences in their food habits. However, the digestive system of fish has most likely adapted to the food niche available during evolution $[26,27]$. Thus, carnivorous fish species are characterised by high lipase and protease activity and low carbohydrase activity [23]. In the present study, this was reflected in high $\mathrm{AD}$ of crude fat and crude protein in both Eurasian perch and Arctic charr, while the digestibility of starch was low.

It has been shown that increasing the water temperature from 
Citation: Abro R, Lundh T, Lindberg JE (2013) Effect of Dietary Starch Inclusion Rate on Digestibility and Amylase Activity in Arctic charr (Salvelinus alpinus) and Eurasian perch (Perca fluviatilis). J Aquac Res Development 5: 209 doi:10.4172/2155-9546.1000209

0.6 to $10^{\circ} \mathrm{C}$ has a positive effect on the $\mathrm{AD}$ of $\mathrm{DM}$, lipids, protein and carbohydrates in a low fat diet fed to Arctic charr [6]. However, increasing the water temperature from 18 to $25^{\circ} \mathrm{C}$ has no effect on the $\mathrm{AD}$ of dietary components in European sea bass [28], although carbohydrate digestion increases in vitro with increasing incubation temperature $\left(5,18\right.$ and $\left.25^{\circ} \mathrm{C}\right)$ of gut tissues from Atlantic salmon (Salmo salar), European sea bass and gilthead sea bream [29]. Thus, it is possible that the difference in $\mathrm{AD}$ between European perch and Arctic charr in the present study was due, at least in part, to differences in water temperature in the tanks $\left(21\right.$ and $10^{\circ} \mathrm{C}$, respectively).

In both Eurasian perch and Arctic charr, the $\mathrm{AD}$ of $\mathrm{DM}$ and $\mathrm{GE}$ was higher at a starch inclusion level of $10 \%$ (diet WS10) than in the control (WS0). There were no differences between the control and the other diets with higher starch inclusion levels in Arctic charr, but in Eurasian perch the AD of DM at $20 \%$ starch inclusion was higher than in the control diet. This indicates that it can be beneficial for overall diet utilisation to include starch in the diet of both Arctic charr and Eurasian perch, but that the inclusion levels should be kept low.

Starch digestibility was highest at the lowest level of wheat starch inclusion in both Eurasian perch (statistically significant) and in Arctic charr (non-significant), with no change in the $\mathrm{AD}$ at higher inclusion levels. A similar effect was found for the AD of starch in silver perch (Bidyanus bidyanus) fed increasing levels of wheat starch [14] and pikeperch fed increasing levels of maize starch [10]. The present study showed that there is an upper limit to starch digestion in both species, but with higher capacity in Eurasian perch than Arctic charr. Moreover, the $\alpha$-amylase activity in the proximal and distal intestine of Arctic charr and Eurasian perch was not significantly affected by dietary starch inclusion. This is in agreement with [8], who reported that inclusion of wheat starch in the diet did not affect $a$-amylase activity in the proximal and distal intestine of silver perch. This suggests that inclusion of starch in the diet will not induce increased $\alpha$-amylase activity in the intestine of Arctic charr and Eurasian perch.

Overall, $\alpha$-amylase activity in fish fed different dietary starch levels exhibited no significant differences within species, and the results followed a similar trend to those described for digestibility of starch. The $\alpha$-amylase activity in the proximal and distal intestine was greater in Eurasian perch than in Arctic charr. This was in line with the higher $\mathrm{AD}$ of starch in Eurasian perch compared with Arctic charr. It has been suggested that the inherited $\alpha$-amylase activity in fish is correlated with dietary carbohydrate levels [30]. Thus, the feeding habits of Eurasian perch and Arctic charr may explain the differences in a-amylase activity observed here.

The distribution pattern of digestive enzymes along the gut differs among fish species $[31,32]$. In the present study, $\boldsymbol{\alpha}$-amylase activity was higher in the proximal than in the distal intestine in both Eurasian perch and Arctic charr. A similar pattern has been found for $\alpha$-amylase activity on comparing the anterior and posterior intestine in gilthead sea bream, while there was no difference in $\alpha$-amylase activity between the sites in European sea bass [29].

\section{Conclusions}

In general, Eurasian perch showed higher digestibility of dietary components and energy than Arctic charr. This difference was most pronounced for starch and was supported by differences in $\alpha$-amylase activity in the proximal and distal intestine. The data suggest that it can be beneficial for overall diet utilisation to include starch in the diet of both Arctic charr and Eurasian perch, but the inclusion levels should be low.

\section{Acknowledgments}

This work was supported by a grant from Formas (Swedish Research Council for Environment, Agricultural Sciences and Spatial Planning). We gratefully acknowledge $\mathrm{Dr}$. David Morrison, Department of Biomedical Sciences and Veterinary Public Health, Swedish University of Agricultural Sciences, for help in preparing the manuscript and Mr. Mazyar Arash Nia for help with the experimental work. Rani Abro was funded by Islamic Development Bank.

\section{References}

1. Kestemont P, Dabrowski K (1996) Recent Advances in the Aquaculture of Percid Fish. J Appl Ichthyol 12: 137-137.

2. Paisley LG, Ariel E, Lyngstad T, Jonsson G, Vennerstrom P, Et Al (2010) An Overview of Aquaculture in The Nordic Countries. J World Aquacult Soc 41: $1-17$.

3. Dalsgaard J, Lund I, Thorarinsdottir R, Drengstig A, Arvonen K, et al (2013) Farming Different Species in RAS In Nordic Countries: Current Status And Future Perspectives. Aquacult Eng 53:2-13.

4. Fiogbe ED, Kestemont P, Melard C, Micha JC (1996) The Effects of Dietary Crude Protein on Growth of The Eurasian Perch Perca Fluviatilis. Aquaculture 144: $239-249$

5. Xu XL, Fontaine P, Melard C, Kestemont P (2001) Effects of Dietary Fat Levels on Growth, Feed Efficiency and Biochemical Compositions of Eurasian Perch Perca Fluviatilis. Aquacult Int 9: 437-449.

6. Olsen RE, Ringo E (1998) The Influence of Temperature on The Apparent Nutrient and Fatty Acid Digestibility of Arctic Charr, Salvelinus Alpinus L. Aquac Res 29: 695-701.

7. Wilson RP (1994) Utilization of Dietary Carbohydrate by Fish. Aquaculture 124 67-80.

8. Stone DAJ (2003) Dietary Carbohydrate Utilization by Fish. Rev Fish Sci 11 337-369

9. Fontaine P Gardeur JN Kestemont P, Georges A (1997) Influence of Feeding Level on Growth, Intraspecific Weight Variability and Sexual Growth Dimorphism of Eurasian Perch Perca Fluviatilis L. Reared in a Recirculation System. Aquaculture 157: 1-9.

10. Nyina-Wamwiza L, Xu XL, Blanchard G, Kestemont P (2005) Effect of Dietary Protein, Lipid and Carbohydrate Ratio on Growth, Feed Efficiency and Body Composition of Pikeperch Sander Lucioperca Fingerlings. Aquac Res 36: 486492.

11. Hemre GI, Torrissen O, Krogdahl A, Lie O (1995) Glucose Tolerance in Atlantic Salmon, Salmo Salar L., Dependence on Adaption to Dietary Starch and Water Temperature. Aquacult Nutr 1: 69-75.

12. Enes $P$, Panserat S, Kaushik S, Oliva-Teles A (2011) Dietary Carbohydrate Utilization by European Sea Bass (Dicentrarchus Labrax L.) and Gilthead Sea Bream (Sparus Aurata L.) Juveniles. Rev Fish Sci 19: 201-215.

13. Shiau SY (1997) Utilization of Carbohydrates in Warmwater Fish-With Particular Reference to Tilapia, Oreochromis Niloticus X O-Aureus. Aquaculture 151: 79 96 .

14. Stone DAJ, Allan GL, Anderson AJ (2003) Carbohydrates Utilization by Juveline Silver Perch, Bidyanus Bidyanus. II. Digestibility and Utilization of Starch and Its Breakdown Products. Aquac Res 34: 109-121.

15. Wilson RP, Poe WE (1987) Apparent Inability of Channel Catfish to Utilize Dietary Monosaccharides and Disaccharides as Energy-Sources. J Nutr 117 280-285.

16. Shiau SY, Lin SF (1993) Effect of Supplemental Dietary Chromium And Vanadium on The Utilization of Different Carbohydrates in Tilapia, OreochromisNiloticusxo-Aureus. Aquaculture 110: 321-330

17. Lin JH, Shiau SY (1995) Hepatic Enzyme Adaptation to Different Dietary Carbohydrates in Juvenile Tilapia Oreochromis-Niloticus $X$ OreochromisAureus. Fish Physiol Biochem 14: 165-170.

18. Infante JL, Cahu C (1994) Development And Response to A Diet Change of Some Digestive Enzymes in Sea Bass (Dicentrarchus-Labrax) Larvae. Fish Physiol Biochem 12: 399-408.

19. Peres A, Cahu CL, Infante JLZ, Legall MM, Quazuguel P (1996) Amylase and 
Citation: Abro R, Lundh T, Lindberg JE (2013) Effect of Dietary Starch Inclusion Rate on Digestibility and Amylase Activity in Arctic charr (Salvelinus alpinus) and Eurasian perch (Perca fluviatilis). J Aquac Res Development 5: 209 doi:10.4172/2155-9546.1000209

Page 5 of 5

Trypsin Responses to Intake of Dietary Carbohydrate and Protein Depend on the Developmental Stage in Sea Bass (Dicentrarchus Labrax) Larvae. Fish Physiol Biochem 15: 237-242.

20. Cho CY, Slinger SJ, Bayley HS (1982) Bioenergetics of Salmonid Fishes Energy-Intake, Expenditure and Productivity. Comp Biochem Phys B 73: 25-41.

21. Bradford MM (1976) Rapid and Sensitive Method for Quantitation Of Microgram Quantities of Protein Utilizing Principle of Protein-Dye Binding. Anal Biochem 72: $248-254$

22. Short FJ, Gorton P, Wiseman J, Boorman KN (1996) Determination of Titanium Dioxide Added as an Inert Marker in Chicken Digestibility Studies. Anim Feed Sci Tech 59: 215-221.

23. Rust MB (2002) Nutritional Physiology.In: Fish Nutrition, 3rd Edition (Halver, JE And RW Hardy, Eds) San Diego, CA, Academic Press, Pp 367-505.

24. Forde-Skjaervik O, Refstie S, Aslaksen MA, Skrede A (2006) Digestibility of Diets Containing Different Soybean Meals In Atlantic Cod (Gadus Morhua) Comparison of Collection Methods and Mapping of Digestibility in Different Sections of The Gastrointestinal Tract. Aquaculture 261: 241-258.

25. Krogdahl A, Hemre GI, Mommsen TP (2005) Carbohydrates in Fish Nutrition: Digestion and Absorption in Postlarval Stages. Aquacult Nutr 11: 103-122.

26. Chakrabarti I, Gani A, Chaki KK, Sur R, Misra KK (1995) Digestive Enzymes in 11 Fresh-Water Teleost Fish Species in Relation to Food Habit And Niche Segregation. Comp Biochem Phys A 112: 167-177.

27. Buddington RK, Christofferson JP (1985) Digestive and Feeding Characteristics of the Chondrosteans. Environ Biol Fish 14: 31-41.

28. Moreira IS, Peres H, Couto A Enes P Oliva-Teles A (2008) Temperature and Dietary Carbohydrate Level Effects on Performance and Metabolic Utilisation of Diets In European Sea Bass (Dicentrarchus Labrax) Juveniles. Aquaculture 274: 153-160.

29. Papoutsoglou ES, Lyndon AR (2005) Effect Of Incubation Temperature On Carbohydrate Digestion In Important Teleosts For Aquaculture. Aquac Res 36 : 1252-1264.

30. Kuzmina VV (1996) Influence of Age on Digestive Enzyme Activity in Some Freshwater Teleosts. Aquaculture 148: 25-37.

31. Rathore RM, Kumar S, Chakrabarti R (2005) Digestive Enzyme Patterns and Evaluation of Protease Classes In Catla Catla (Family : Cyprinidae) During Early Developmental Stages. Comp Biochem Phys B 142: 98-106.

32. Skea GL, Mountfort DO, Clements KD (2005) Gut Carbohydrases From The New Zealand Marine Herbivorous Fishes Kyphosus Sydneyanus (Kyphosidae), Aplodactylus Arctidens (Aplodactylidae) and Odax Pullus (Labridae). Comp Biochem Phys B 140: 259-269. 